
ISSN : 2615-1995, E-ISSN : 2615-0654

J. Madani., Vol. 2, No. 2, September 2019 (331 - 341)

(C)2018 Lembaga Kajian Demokrasi

MADANI

dan Pemberdayaan Masyarakat (LKD-PM)

\title{
Peran Pendidikan Karakter dan Kreativitas Siswa Dalam Menghadapi Era Revolusi Industri 4.0
}

\author{
Irma Budiana \\ Sekolah Tinggi Ilmu Tarbiyah Islamic Village \\ irmabudianaa@gmail.com \\ Try Apriani Atieka \\ Sekolah Tinggi Ilmu Tarbiyah Islamic Village \\ triapriani15@gmail.com
}

\begin{abstract}
Abstrak
Penelitian ini bertujuan untuk menelaah atau mengkaji peran pendidikan karakter terhadap kreativitas siswa dalam menghadapi era revolusi industri 4.0. Jenis penelitian ini adalah kualitatif, dengan meneliti sejumlah buku-buku yang berkaitan dengan masalah yang dibahas. Kajian peran pendidikan karakter dan kreativitas siswa dalam mengahadapi era revolusi industri 4.0 ini bertujuan untuk membentuk karakter yang baik dalam diri siwa yang dibekali dengan kemampuan intelegensi, kemampuan agama, dan kemampuan kreativitas yang tinggi, agar berguna bagi dirinya sendiri, agama, bangsa dan negara. Seorang siswa tidak akan memiliki kepribadian yang baik jika tidak diberikan pendidikan yang syarat dengan nilai-nilai pendidikan karakter. Pendidikan itu juga harus melalui pembiasaan dalam kehidupan sehari-hari. Berdasarkan hasil penelitian disimpulkan bahwa (1) nilai-nilai yang terkandung pendidikan karakter akan membentuk manusia secara utuh (holistik) yang berkarakter, yaitu mengembangkan aspek fisik, emosi, sosial, kreativitas, dan intelektual siswa secara optimal yang berlandaskan iman dan takwa kepada tuhan yang Maha Esa. (2) pendidikan karakter harus diberikan secara menyeluruh baik melalui lingkungan keluarga, sekolah, dan masyarakat. (3) dengan kreativitas yang tinggi akan membuat siswa lebih tangguh dalam menghadapi berbagai permasalahan dalam hidup. Siswa akan lebih memiliki ide, gagasan, dan penyelesaian dalam memecahkan masalah yang dihadapi. (3) era revolusi industri 4.0 bukanlah era yang harus ditakuti, namun era yang memberikan tantangan tersendiri bagi siswa yang memang harus dihadapi dengan berbagai pengetahuan dan keterampilan. (4) pendidikan karakter mempunyai peran yang sangat penting dalam membentuk kreativitas siswa sehinnga siswa lebih siap dan tangguh dalam menghadapi tantangan yang ada di era revolusi industri 4.0.
\end{abstract}

Kata Kunci: Pendidikan Karakter, Kreativitas Siswa, Era Revolusi Industri 4.0

\begin{abstract}
The purpose of this research are examining the role of character education on students' creativity in facing the era of industrial revolution 4.0. The type of research is qualitative, by examining a number of books relating to the problems discussed. The study of the role of character education and creativity of students in dealing with the industrial revolution era 4.0 aims to form a good character in students who are equipped with intelligence, religious ability, and high ability of creativity to be useful for themselves, religion, nation and country. A student will not have a good personality if not given an education that is conditional on character education values. Education must also be through habituation in everyday life. The result show that: (1) the values contained in character education will form a whole (holistic) character with character, namely developing physical,
\end{abstract}


emotional, social, creativity, and intellectual aspects of students optimally based on faith and piety to God Almighty. (2) character education must be given thoroughly both through the family, school and community environment. (3) with high creativity will make students more resilient in dealing with various problems in life. Students will have more ideas, ideas, and solutions in solving problems faced. (3) the era of industrial revolution 4.0 is not an era that must be feared, but an era that presents its own challenges for students who indeed must be faced with various knowledge and skills. (4) character education has a very important role in shaping students' creativity so that students are more prepared and resilient in facing challenges that exist in the era of industrial revolution 4.0.

\section{Keyword: Character Education, Students' Creativity, Era of Industrial Revolution 4.0}

\section{PENDAHULUAN}

\section{Latar Belakang}

Perubahan zaman yang begitu cepat sebagai konsekuensi dari modernisasi dan kemajuan ilmu pengetahuan dan teknologi yang semakin canggih, telah mengakibatkan terjadinya perubahan tatanan sosial, ekonomi dan budaya. Menurut Sumardianta dan Wahyu Kris AW (2018) dalam Kasali tentang disruption, segala aspek kehidupan sedang dilanda disrupsi. Ini semacam serangan inovasi. Kehidupan tidak bisa dijalani hanya dengan iterasi (melakukan hal yang sama dengan cara lebih baik, doing the new thing) dan inovasi (membuat hal-hal baru, doing the new thing). Strategi terbaik menata masa depan yang lebih baik adalah disrupsi (membuat banyak hal baru, doing things differently).

Menurut Forkomsi FEB UGM (2019) era revolusi industri 4.0 ini otomatisasi, komputerisasi, dan digitalisasi akan melahirkan terobosanterobosan baru di berbagai bidang yang mendisrupsi (mengubah cara fundamental kehidupan kita). Menghadapi tantangan teknologi tersebut, maka diperlukan pendidikan karakter yang baik untuk berubah dalam segala sektor, agar setiap orang mampu bersaing dan memiliki keterampilan dalam menghadapi masa depan. Sementara itu dalam tatanan kehidupan banyak ditemukan anak-anak yang tidak berkarakter.

Menurut survei yang dilakukan di kota Tangerang dan wawancara dengan beberapa anak jalanan disimpulkan beberapa generasi muda banyak yang terjerumus ke dalam pergaulan bebas yang mengakibatkan rusaknya moral, dan banyak pula diantaranya alim dan baik di rumah, namun ketika berada di luar rumah menjadi nakal dan terlibat dalam tawuran, di samping itu banyak pula diantara anak yang secara IQ mempunyai potensi yang baik, namun antara kecerdasan intelektual, kecerdasan emosional, dan kecerdasan spiritual tidak terintegrasi secara utuh. Hal ini disebabkan karena tidak mendapatkan pendidikan yang baik, maka menjadi generasi yang bermalas-malasan, emosional, tidak bermoral, tidak suka bekerja keras dan tidak mempunyai kreativitas. Sementara itu, persaingan dan tuntutan hidup semakin keras, seiring kemajuan teknologi yang semakin canggih. Hal ini banyak menyebabkan generasi muda mengalami kegoncangan jiwa, gelisah oleh perasaan-perasaan yang membuat khawatir dalam menghadapi persaingan hidup. Salah satu penyebabnya adalah karena kurangnya pengetahuan, kemampuan, dan karakter yang tangguh dalam diri.

Alam dan Rukaya (2019) mengemukakan pendidikan merupakan bagian penting dari kehidupan manusia yang tidak pernah bisa ditinggalkan. Indonesia sebagai salah satu negara dengan penduduk terbesar di dunia, menjadi barometer negara-negara Asia dalam mengatur masyarakatnya dengan berbagai macam pendidikan. Guru diharapkan mampu memberikan kepada siswa keterampilan yang dibutuhkan oleh Revolusi Industri keempat, yaitu kemampuan teknis, kreativitas, dan pemecahan masalah yang inovatif. Dengan demikian pada era teknologi saat ini menjadikan pendidikan karakter merupakan salah satu kebutuhan yang tidak terelakan. Pendidikan karakter merupakan salah satu kunci utama bagi manusia dalam mengarungi kehidupan. Banyak orangyangingin mencurahkan semua perhatian dan usaha semaksimal mungkin untuk mencapai pendidikan yang lebih baik dan 
lebih tinggi, salah satunya dengan pendidikan karakter harapan akan memperoleh kehidupan yang lebih baik akan terwujud. Berdasarkan hal-hal yang telah dijabarkan di atas, peneliti ingin melakukan penelitian yang berjudul Peran Pendidikan Karakter Dan Kreativitas Siswa Dalam Menghadapi Era Revolusi Industri 4.0.

\section{Pembatasan Masalah}

Penelitian ini dibatasi dengan Peran Pendidikan Karakter dan Kreativitas Siswa Dalam Menghadapi Era Revolusi Industri 4.0.

\section{METODE}

Metode yang digunakan pada penelitian ini adalah studi literatur. Adapun jenis penelitian ini adalah kualitatif dengan meneliti sejumlah buku-buku yang berkaitan dengan masalah yang dibahas. Kajian peran pendidikan karakter dan kreativitas siswa dalam mengahadapi era revolusi industri 4.0 bertujuan untuk membentuk karakter yang baik dalam diri siwa yang dibekali dengan kemampuan intelegensi, kemampuan agama, dan kemampuan kreativitas yang tinggi, agar berguna bagi dirinya sendiri, agama, bangsa dan negara.

\section{HASIL dan PEMBAHASAN}

\section{Era Revolusi Industri 4.0}

Perkembangan ilmu pengetahuan dan teknologi telah mengubah dunia sebagaimana revolusi generasi pertama melahirkan sejarah ketika tenaga manusia dan hewan digantikan oleh kemunculan mesin. Era revolusi industri $4.0 \mathrm{da}$ lam Forum Komunikasi Mahasiswa Magister Sains (Forkomsi) FEB UGM (2019) adalah era yang menekankan pada pola digital economy, artificial intelligence, big data, robotic, dan lain sebagainya atau dikenal dengan fenomena disruptive innovation. Pada era digital ini tenaga manusia banyak digantikan dengan mesin otomatis. Menurut Kusnadi (2019) era revolusi industri 4.0 akan menyebabkan ketidaksetaraan yang lebih tinggi, karena teknologi yang muncul akan mengambil alih pekerjaan padat karya. Artinya, teknologi tingkat tinggi akan mengambil alih pekerjaan yang sebelumnya banyak tenaga manusia. Perubahan yang terjadi berpengaruh pada karakter pekerjaan sehingga keterampilan yang diperlukan juga akan berubah. Tantangan tersebut, harus dapat diantisipasi melalui transformasi pasar kerja Indonesia dengan mempertimbangkan perubahan iklim bisnis dan industri, perubahan pekerjaan dan kebutuhan keterampilan.

Menurut Imaduddin (2018) tantangan industri 4.0 diantaranya yaitu kesiapan industri, tenaga kerja terpercaya, kemudahan pengaturan sosial budaya, diversifikasi, dan penciptaan lapangan kerja dan peluang industri. Secara detail tantangan yang akan terjadi pada revolusi industri 4.0 adalah sebagai berikut:

1) Menimbulkan masalah pada keamanan data dan terjaganya privasi seseorang;

2) Terjadinya ketidaksetaraan yang lebih besar di pasar tenaga kerja;

3) Menurunnya pendapatan riil pekerja saat mesin mengambil alih pekerjaan mereka;

4) Pengalihan pekerjaan dari tenaga kerja manusia oleh mesin dan kecerdasan buatan;

5) Penciptaan pekerjaan manusia tingkat tinggi selalu menjadi perhatian ketika teknologi otomatis mengambil alih pekerjaan seharihari;

6) Terjadinya cyber crime dan penyalahgunaan data di berbagai bidang kehidupan ideologi, sosial, budaya, dan keamanan semakin sulit dicegah;

7) Eksploitas sumber daya alam yang lebih massive berdampak berbagai bencana ekologi mematikan kian meluas dan kian sering.

\section{Dampak Positif Revolusi Industri 4.0}

Dampak positif revolusi industri 4.0 menurut Kusnadi (2019) antara lain:

1) Kenaikan tingkat pendapatan global;

2) Peningkatan kualitas hidup dengan teknologi tingkat yang lebih tinggi;

3) Pengurangan biaya transportasi dan komunikasi;

4) Penciptaan produk dan pasar baru;

5) Terwujudnya tempat kerja yang aman bagi pekerja karena pekerjaan yang beresiko tinggi atau berbahaya diambil ahli oleh robot; 
6) Peningkatan layanan kesehatan yang mengarah semakin panjangnya kesempatan hidup manusia.

\section{Dampak Negatif Revolusi Industri 4.0}

Dampak negatif era revolusi industri 4.0 menurut Imaduddin (2018) diantaranya adalah:

1) Permasalahan pengangguran; Work Employment and Social Outlook Trend 2017 memprediksi jumlah orang yang menganggur secara global pada 2018 diperkirakan mencapai angka 204 juta jiwa dengan kenaikan bertambah 2,7 juta.

2) Perlunya persiapan sistem pembelajaran yang lebih inovatif seperti penyesuaian kurikulum pembelajaran, meningkatkan kemampuan siswa dalam hal data Information Technology (IT), Operational Technology (OT), Internet of Things (LoT), dan Big Data Analitic, mengintegrasikan obyek fisik, digital dan manusia untuk menghasilkan lulusan yang kompetitif dan terampil.

\section{Pendidikan Karakter}

\section{Pengertian Pendidikan Karakter}

Menurut Aeni (2014) istilah karakter diambil dari bahasa Yunani "Charaasian" yang berarti "to mark" atau menandai dan memfokuskan bagaimana mengaplikasikan nilai kebaikan dalam bentuk tindakan atau tingkah laku, sehingga orang yang tidak jujur, kejam, rakus dan perilaku jelek lainnya dikatakan orang berkarakter jelek. Sebaliknya, orang yang perilakunya sesuai dengan kaidah moral disebut dengan berkarakter mulia. Hal ini sesuai dengan makna karakter yang dimaknai oleh Tilaar sebagai sifat-sifat hakiki seseorang atau suatu kelompok atau bangsa yang sangat menonjol sehingga dapat dikenali dalam berbagai situasi.

Menurut Yaumi (2014) karakter dalam bahasa agama disebut sebagai akhlak. Akhlak merupakan istilah dalam bahasa Arab yang merujuk pada praktik-praktik kebaikan, moralitas, dan prilaku yang baik. Istilah akhlak sering diterjemahkan dengan perilaku Islami (islamic behavior), sifat atau watak (dispotion), perilaku baik (good con$d u c t$ ), kodrat atau sifat dasar (nature), perangai (temper), etika atau tata susila (ethics), moral, dan karakter. Menurut Hidayatullah (2010) karakter adalah sifat kejiwaan, akhlak atau budi pekerti yang membedakan seseorang dari tabiat, watak. Berkarakter artinya mempunyai watak, mempunyai kepribadian. Sodiq (2018) mengemukakan karakter adalah nilai yang melembaga dalam diri seseorang yang dikenali sebagai sifat. Karakter bukanlah watak bawaan, akan tetapi sesuatu yang dibentuk berdasarkan pengalaman dan pembiasaan. Proses membangun sebuah karakter adalah proses penanaman nilai pada diri seseorang sehingga benar-benar menjadi sifat yang menetap dalam jiwa.

Rosidatun(2018) mengemukakan pendidikan karakter didefinisikan sebagai pendidikan yang mengembangkan karakter yang mulia (good character) dari siswa dengan mempraktikan dan mengajarkan nilai-nilai moral dan pengambilan keputusan yang beradab dalam berhubungan dengan Tuhan. Anam dalam Fadillah \& Mualifatu (2013) mendefinisikan pendidikan karakter sebagai proses internalisasi budaya ke dalam diri seseorang dan masyarakat sehingga membuat orang dan masyarakat beradab. Pendidikan bukan merupakan sarana transfer ilmu pengetahuan saja, melainkan lebih luas lagi, yakni sebagai sarana pembudayaan dan penyaluran nilai (enkulturisasi dansosialisasi). Octavia, Ibi Syatibi, Mukti Ali (2014) pendidikan karakter meniscayakan pengembangan kepribadian serta pengembangan keterampilan.

Hal ini setidaknya merujuk pada adanya tiga unsur pokok dalam pembentukan karakter yaitu mengetahui kebaikan (knowing the good), mencintai kebaikan (loving the good), dan melakukan kebaikan (doing the good). Kebaikan dalam pendidikan berkarakter seringkali dirangkum dalam sederet sifat-sifat baik. Dengan demikian, pendidikan karakter adalah sebuah upaya untuk membimbing perilaku manusia menuju standarstandar baku tentang sifat-sifat baik.

\section{Nilai-nilai Pendidikan Karakter}

Menurut Megawangi (2004) dalam Indonesia Heritage Foundation (IHF) telah menyusun serangkaian nilai yang selayaknya diajarkan kepada anak-anak, yang kemudian dirangkum 
menjadi 9 pilar karakter, yaitu:

1) Cinta Tuhan dan segenap ciptaan-Nya (love Allah, trust, reverence, loyality).

Agama meliputi keseluruhan tingkahlaku manusia dalam hidup ini, yang tingkahlaku itu membentuk keutuhan manusia berbudi luhur (berakhlakul karimah), atas dasar percaya atau iman kepada Allah SWT dan tanggungjawab pribadi di hari kemudian. Dalam hal ini agama mencakup totalitas tingkahlaku manusia dalam kehidupan sehari-hari yang dilandasi dengan iman kepada Allah SWT, sehinggah tingkahlakunya berlandaskan keimanan dan akan membentuk akhlakul karimah yang terbiasa dalam pribadi dan perilakunya sehari-hari. Ainun (2012).

2) Kemandirian dan tanggung jawab, (responsibility, exellence, self realiance, discipline, orderliness).

Salahudin, Alkrienciehie (2017) mengatakan bahwa mandiri adalah sikap dan perilaku yang tidak mudah bergantung pada orang lain dalam menyelesaikan tugas-tugas. Pribadi sukses biasanya telah memiliki kemandirian sejak kecil. Ainun (2012) menjelaskan mandiri adalah sikap terbiasa berha dapan dengan banyak hambatan dan tantangan. Sifat mandiri yang memungkinkan anak teguh menghadapi berbagai tantangan sehingga akhirnya menuai kesuksesan. Yaumi (2014) menyatakan bahwa tanggung jawab adalah karakter yang dimiliki seseorang untuk melaksanakan tugas dan kewajibannya sebagaimana seharusnya dilakukan baik terhadap diri sendiri, masyarakat, lingkungan dan Tuhan.

3) Kejujuran, amanah, bijaksana (trustworthiness, reliability, honesty).

Kurniawan dan Hindarsih (2013) berpendapat jujur berarti sesuai antara hati dan perkataannya. Berkata apa adanya, tidak berbohong, tidak melakukan kecurangan dalam permainan dan perbuatan lainnya. Salahudin dan Alkrienciehie (2017) menyatakan kejujuran merupakan prilaku yang didasarkan pada upaya menjadikan dirinya sebagai orang yang selalu dapat dipercaya dalam per- kataan, tindakan dan pekerjaan.

4) Hormat dan santun (respect, courtessy, obedience).

Menghormati artinya menaruh hormat, takzim, dan sopan. Menghormati bisa diartikan sebagai menghargai atau menjunjung tinggi. Menghormati berarti mengakui dan menaati.

5) Dermawan, suka menolong dan gotong royong (love, compassion, caring, empathy, generousity, moderation, cooperation)

6) Percaya diri, kreatif, dan pekerja keras (confidence, assertiveness, creativity, resourcefulness, courage, determination and enthusiasm). Taylor (2013) percaya diri merupakan kemampuan menjadi diri sendiri serta mencoba apapun dalam artian positif, tanpa merasa takut atau malu. Orang yang percaya diri akan lebih berani untuk melakukan segala sesuatu dalam menuangkan kreativitasnya untuk mencipta. Orang yang kreatif biasanya selalu ingin tahu tentang segala hal, sehingga dia selalu aktif dan bekerja keras untuk menciptakan sesuatu yang baru dan bermanfaat. Menurut Arnold Toyabel, Peradaban tumbuh sebagai hasil dari respon inovatif minoritas orang-orang kreatif terhadap tantangan lingkungannya.

7) Kepemimpinan dan keadilan (justice, fairness, mercy, leadership).

Menurut Lickona (2004) keadilan berarti menghormati semua hak-hak orang. Aturan emas (The Golden Rule), yang mengarahkan kita untuk memperlakukan orang lain sebagaimana kita ingin diperlakukan oleh orang lain, adalah prinsip keadilan yang dapat ditemukan dalam budaya dan agama di seluruh dunia.

8) Baik dan rendah hati (kindness, friendliness, humility, modesty).

Kurniawan dan Hindarsih (2013) rendah hati adalah perilaku yang menunjukkan tidak sombong dan tidak angkuh. Berkata yang santun, merendahkan suara, orang yang rendah hati sangat santun. Kemampuan rendah hati akan berdampak peduli kepada orang lain. Kemampuan rendah hati juga berujung pada kemampuan untuk meng- 
hargai orang lain.

9) Toleransi, kedamaian dan kesatuan (tolerance, flexibility, peacefulness, unity).

Tillman (2004) menyatakan karakter toleransi sebagai sikap saling menghargai melalui pengertian dengan tujuan kedamaian

\section{Tujuan Pendidikan Karakter}

Menurut Zubaidi (2013) ada beberapa fungsi diadakannya pendidikan karakter yaitu:

a) Fungsi pembentukan dan pengembangan potensi

Pada fungsi ini pendidikan karakter berfungsi untuk membentuk dan mengembangkan potensi peserta didik agar berpikiran baik, berhati baik, dan berperilaku baik.

b) Fungsi perbaikan dan penguatan

Fungsi perbaikan dan penguatan dimaksudkan bahwa pendidikan karakter berfungsi memperbaiki dan memperkuat peran keluarga, satuan pendidikan, masyarakat, dan pemerintah untuk ikut berpartisipasi dan bertanggung jawab dalam mengembangkan potensi warga negara dan pembangunan bangsa menuju bangsa yang maju, mandiri dan sejahtera.

c) Fungsi penyaring

Fungsi penyaring adalah untuk memilih budaya sendiri dan menyaring budaya bangsa lain yang tidak sesuai dengan nilai-nilai budaya dan karaker bangsa yang kuat. Menurut Suwito, Mulyadi, Hanum (2008) pendidikan karakter menurut Heritage Foundation bertujuan membentuk manusia secara utuh (holistik) yang berkarakter, yaitu mengembangkan aspek fisik, emosi, sosial, kreativitas, spiritual, dan intelektual siswa secara optimal. Selain itu juga untuk membentuk manusia yang lifelong learners (pebelajar sejati). Menurut Narwati (2011) inti tujuan pendidikan karakter adalah untuk membentuk bangsa yang tangguh, kompetitif, berakhlak mulia, bertoleran, bermoral, bergotong royong, berjiwa patriotik, berkembang dinamis, berorientasi ilmu pengetahuan dan teknologi yang semuanya dijiwai oleh iman dan takwa kepada Tuhan yang maha Esa.

\section{Peran Pendidikan Karakter \\ Dalam Menghadapi Era Revolusi Industri 4.0}

Menurut Syarbini (2014) bangsa Indonesia saat ini diyakini sedang mengalami krisis moral atau akhlak hampir pada semua segmen kehidupan dan seluruh lapisan masyarakat. Fenomena kerusakan moral atau akhlak yang menimpa masyarakat telah mendorong pemerintah Indonesia untuk menerapkan kebijakan nasional pembangunan karakter bangsa (KN-PKB). Salah satu upaya untuk mewujudkan kebijaksanaan tersebut adalah dengan menekankan pentingnya pendidikan karakter untuk diimplementasikan dalam setiap institusi pendidikan, baik formal (sekolah), informal (keluarga) maupun non formal (masyarakat).

Keluarga memiliki peran sentral dalam proses pembentukan kepribadian anak, keluarga sebagai sebuah lembaga utama tempat anak menemukan pertumbuhan melalui ikatan emosional yang intim, mengalami rasa aman, terlindung, dan dicintai. Ini semua tidak dapat diberikan oleh pelaku pendidikan lain di luar lembaga keluarga. Koesoema (2007) menyatakan bahwa tugas orang tua adalah sebagai lahan tempat anak itu kelak semakin mampu mengembangkan kepribadiannya sehingga anak benar-benar siap dan terampil ketika harus terjun ke dalam kehidupan bermasyarakat.

Koesoema (2007) menyatakan bahwa lembaga pendidikan, dalam hal ini sekolah terutama memberikan pendidikan intelektual. Kadang mereka juga memiliki visi tentang pemahaman akan nilai yang dibentukkan, seperti nilai ketekunan, kreativitas, dan sopan santun. Masyarakat luas memberikan pendidikan secara khas sesuai dengan pendekatan khusus atas tujuan pendidikan yang menjadi arah dan sasaran mereka, misalnya kehadiran sejumlah balai pelatihan dan lembaga kursus. Lembaga agama tidak ketinggalan ikut serta dalam menumbuhkan dan mengembangkan daya-daya kerohanian di dalam diri siswa sehingga mereka mampu menghayati diri sendiri sebagai individu dan pribadi yang memiliki rasa religius kuat. 
Koesema (2007) Pendidikan karakter di sekolah secara sederhana bisa didefinisikan sebagai pemahaman, perawatan, dan pelaksanaan keutamaan (practice of virtue). Oleh karena itu pendidikan karakter di sekolah mengacu pada proses penanaman nilai, berupa pemahamanpemahaman, tata cara merawat dan menghidupi nilai-nilai itu, serta bagaimana seorang siswa memiliki kesempatan untuk dapat melatihkan nilainilai tersebut secara nyata.

Guru juga mempunyai peranan yang sangat penting dalam proses pengubahan perilaku dan kemampuan siswa, menurut Sagala (2017) guru yang mampu mencapai golongan tertinggi pada dasarnya adalah guru-guru yang kreatif, inovatif, ulet, tangguh, dan gigih dalam memecahkan masalah berbagai masalah layanan belajar yang dihadapinya. Kualitas layanan pendidikan dapat dipenuhi melalui orang-orang yang berprestasi. Pada dasarnya orang tua dan murid akan mendapatkan kepuasan dengan layanan pendidikan yang berkualitas. Sementara, pemerintah dan masyarakat luas memperoleh sumber daya manusia lulusan sekolah yang memiliki kemampuan, kompetensi, pengetahuan, dan kapabilitas yang bermutu sesuai jenjang pendidikan yang ditempuhnya.

Menurut Anshari dan Rais (1988) Pendidikan jika dilihat dalam perspektif Islam, tidak lain kecuali sebagai suatu upaya yang bi-dimensional, tetapi yang tidak dikotomis. Bagi seorang hamba Allah jasmani dan rohani, dunia dan akhirat, bukanlah dua hal yang bertentangan dan yang harus dipisahkan, melainkan mereka merupakan dua serangkai yang harus lengkap melengkapi dan dilebur menjadi satu susunan yang harmonis dan seimbang.

Hidup ini menurut Latuconsina (2017) tidak saja menuntut kita harus pintar, tapi harus lebih pintar. Ijazah dan gelar tidak bisa mengubah kita kalau kita tidak kreatif. Bakat, kecerdasan, ilmu, pengalaman, dan berbagai kekuatan eksternal yang kita miliki tidak bisa banyak bekerja bila kita tidak kreatif.

Rachmawati (2011) mengemukakan bahwa melalui ilmu pengetahuan manusia dapat memperbaiki kekurangannya dan menciptakan hal- hal baru yang berdaya guna dalam kehidupan masyarakat banyak. Tanpa dibarengi dengan rasa keingintahuan yang tinggi, keinginan untuk selalu maju dan meningkatkan diri, jiwa pencari pengetahuan yang besar, serta ide original, manusia tidak akan mencapai perkembangan sepesat ini. Tanpa kekuatan dalam diri manusia yang telah dianugerahkan Tuhan tersebut, tidak akan banyak perubahan dan kemajuan dalam kehidupan kita.

Yuriaan, Prasodjo (2019) di era revolusi industri 4.0, menuntut setiap orang untuk berubah, dan proses perubahan yang dibawa industri 4.0 sangat tidak mudah, penuh dengan tantangan dan mencemaskan, jika kita tidak siap. Di era revolusi industri 4.0 permintaan untuk pekerja berketerampilan tinggi telah meningkat, sementara permintaan untuk pekerja dengan pendidikan yang lebih rendah dan keterampilan yang lebih rendah telah menurun. Menurut Andhara, Umaro, Haris Tua Lubis (2018) mengubah pola pikir dengan berpandangan bahwa dunia ini menuntut adanya inovasi dari setiap individu dan organisasi. Hanya dengan inovasi arus perubahan sekencang apapun dapat dihadapi, dan dengan inovasi memungkinkan pertumbuhan yang berkelanjutan tiada henti. Paul Romer, ekonom asal Amerika, dalam hipotesisnya menyebutkan bahwa inovasi dan knowledge-based product menjadi sumber pertumbuhan tak terbatas bagi sebuah perekonomian.

Pada era disrupsi ini, menurut Setianto dan Anandhita (2018) dunia pendidikan tidak hanya berfokus pada sisi kemajuan teknologi saja, tetapi juga perlu menanamkan nilai-nilai budi pekerti bagi anak didiknya. Selain menanamkan budi pekerti pada siswa, agar mampu bersaing secara positif dalam menghadapi era disrupsi tentunya siswa perlu menguasai ilmu pengetahuan dan teknologi, memiliki etos kerja, sikap terbuka, mampu bekerjasama untuk menyelesaikan berbagai persoalan yang semakin kompleks dan berubah dengan cepat.

Lickona (2012) menyatakan pendidikan karakter merupakan tanggung jawab bersama dari mereka semua yang menyentuh nilai dan kehidupan para anak muda, berawal dengan keluarga dan meluas hingga komunitas iman, orga- 
nisasi pemuda, bisnis, pemerintah, dan bahkan media. Harapan akan masa depan adalah bahwa kita dapat berkumpul bersama dengan penyebab yang sama: mengangkat pendidikan karakter anak-anak kita, karakter kita sendiri sebagai orang dewasa, dan pada akhirnya karakter kebudayaan kita.

Pendidikan karakter mengandung nilai-nilai pendidikan, diantaranya adalah nilai pendidikan kreatif. Menurut Surya (2014) peranan kreatifitas sangat penting dalam mengembangkan kepribadian anak. Anak yang kreatif berarti memiliki kemahiran mempergunakan penalaran, imajinasi, maupun kesanggupan menggerakan kelebihan-kelebihan yang ada pada dirinya untuk menghasilkan gagasan yang asing dan berbeda. Anak lebih mengedepankan cara-cara positif dan konstruktif dalam menyikapi berbagai kesulitan dan pemecahan masalah. Anak yang kreatif juga memperlihatkan intuisi yang kuat dan kemandirian dalam bersikap dan perilaku sosial. Campbell (2012) salah satu hal yang dapat membantu kita hidup di dunia yang makin rumit dan ruwet ini adalah kreativitas.

Dengan demikian pendidikan karakter bagi siswa mempunyai peran yang sangat penting, karena nilai-nilai yang terkandung di dalam pendidikan karakter akan tertanam dalam diri siswa yang akan melahirkan generasi-generasi penerus yang berkualitas, generasi berbobot, generasi yang kreatif, yang akan membawa kemajuan pada masyarakat, bangsa dan agama.

\section{Kreativitas Siswa \\ Pengertian Kreativitas}

Menurut Campbell (2012) kreativitas adalah kegiatan yang mendatangkan hasil yang sifatnya baru, berguna, dan dapat dimengerti. Menurut Wahyudin (2007) kreativitas berarti kemampuan menghasilkan sesuatu yang baru dan orisinil yang berwujud ide-ide dan alat-alat, serta lebih spesifik lagi, keahlian menemukan sesuatu. Gallagher dalam Rachmawati (2011) mengatakan bahwa kreativitas merupakan suatu proses mental yang dilakukan individu berupa gagasan ataupun produk baru, atau mengombinasikan antara keduanya yang pada akhirnya akan melekat pada di- rinya.

Berdasarkan beberapa definisi di atas dapat kita simpulkan bahwa kreativitas merupakan suatu proses mental individu yang menghasilkan sesuatu gagasan, proses, metode ataupun produk baru yang orisinil, efektif yang bersifat imajinatif, dapat mengombinasikan antara beberapa temuan yang akhirnya menghasilkan suatu karya yang baru.

\section{Ciri Kepribadian Orang yang Kreatif}

Menurut Rachmawati (2011) ciri kepribadian orang yang kreatif adalah:

1) Terbuka terhadap pengalaman baru;

2) Fleksibel dalam berfikir dan merespons;

3) Bebas dalam menyatakan pendapat dan perasaan;

4) Menghargai fantasi;

5) Tertarik pada kegiatan kreatif;

6) Mempunyai pendapat sendiri dan tidak terpengaruh oleh orang lain;

7) Mempunyai rasa ingin tahu yang besar;

8) Toleran terhadap perbedaan pendapat dan situasi yang tidak pasti;

9) Berani mengambil resiko yang diperhitungkan;

10) Percaya diri dan mandiri;

11) Memiliki tanggungjawab dan komitmen kepada tugas;

12) Tekun dan tidak mudah bosan;

13) Tidak kehabisan akal dalam memecahkan masalah;

14) Kaya akan inisiatif;

15) Peka terhadap situasi likgkungan;

16) Lebih berorientasi ke masa kini dan masa depan dari pada masa lalu;

17) Memiliki citra diri dan stabilitas emosi yang baik;

18) Tertarik kepada hal-hal yang abstrak, kompleks, holistis, dan mengandung teka-teki;

19) Memiliki gagasan yang orisinal;

20) Mempunyai minat yang luas;

21) Menggunakan waktu luang untuk kegiatan bermanfaat dan konstruktif bagi pengembangan diri;

22) Kritis terhadap pendapat orang lain;

23) Senang mengajukan pertanyaan yang baik; 
24) Memiliki kesadaran etika moral dan estetik yang tinggi.

\section{Cara Menumbuhkan Kreativitas Anak}

Menurut Herwibowo dan Hendroyono (2004) ada beberapa tindakan yang dapat dilakukan untuk memupuk kreativitas anak, diantaranya adalah:

a. Doronglah anak untuk mengekspresikan diri.

b. Hormati cara anak mengekspresikan kreativitasnya.

c. Doronglah anak agar mengekspresikan gagasan tanpa mencela dan membuatnya malu.

Santrock (2007) tentang kondisi yang meningkatkan kreativitas yaitu waktu, kesempatan menyendiri, dorongan, sarana, lingkungan yang merangsang, hubungan orang tua-anak yang tidak posesif, cara mendidik anak dan kesempatan untuk memperoleh pengetahuan. Banyak sekali hal yang harus dilakukan guru untuk memfasilitasi anak dalam mengembangkan kreativitasnya. Mengingat pada kenyataannya banyak sekali guru yang telah mendapatkan pengetahuan tentang kreativitas dan pentingnya kreativitas.

Menurut Wibowo (2010) sekolah juga diingatkan agar tidak lupa membekali seluruh siswanya dalam hal berpikir kritis, memiliki afeksi yang kuat pada sesama, kedewasaan moral, kemampuan kerjasama, keterampilan berkomunikasi, baik secara lisan maupun tulisan, bekerja mandiri, memimpin, beradaptasi secara cepat, dan tanggung jawab, serta memiliki wawasan global. Anak mempunyai motivasi untuk kreatif diperoleh dari orang tua dan guru. Guru sebagai orangtua juga harus membimbing dan membina siswa untuk berpikir kreatif.

Menurut Supriadi dalam Salahudin, Alkrienciehie (2017) yang perlu dikembangkan bagi anak kreatif adalah kesehatan mental, pengembangan diri, prestasi akademik dan karier masa depan. Salahudin dan Alkrienciehie (2017) berpendapat bagi anak kreatif, kesehatan mental yang baik akan bermanfaat untuk mengembangkan kreativitasnya, sebab kesehatan mental yang terganggu secara psikologis akan berakibat pada proses kreativitas tidak berkembang. Orang tua dan guru jangan melakukan kekerasan fisik dan mental pada anak karena akan berpengaruh pada psikologi anak, dan sulit untuk bangkit dalam mengembangkan kreativitasnya.

Salahudin, Alkrienciehie (2017) prinsip dan tujuan adanya pembinaan dan bimbingan adalah mengajarkan anak untuk berani tanpa harus agresif untuk menyadari diri dan lingkungannya. Tujuan pembinaan untuk kondisi bagi mental anak adalah:

a. Bebas dari rasa terancam karena gagasangagasannya;

b. Tumbuhnya kesadaran diri, yaitu "apa yang aku rasakan";

c. Diferensiasi diri, yaitu memandang diri berbeda dengan orang lain disamping adanya kesamaan;

d. Adanya tenggang rasa dan saling menghargai;

e. Hubungan yang menguntungkan antara relasi, yaitu keseimbangan antara usaha membina relasi sosial dengan kehendak menampilkan jati diri.

Melihat kondisi fisik dan psikologis anak, maka orang tua dan guru harus bijaksana dalam mendidik anak karena anak butuh ruang dan waktu, serta tempat untuk menunjukkan dirinya, dengan segala kemampuan yang dimilikinya, dan tujuan pembinaan di atas harus menjadi acuan bagi orang tua dan guru dalam mendidik anak.

\section{SIMPULAN}

Revolusi industri saat ini memasuki fase keempat. Perkembangan ilmu pengetahuan dan teknologi yang sangat pesat memberikan dampak yang besar terhadap kehidupan manusia. Banyak kemudahan dan inovasi yang diperoleh dengan adanya dukungan teknologi digital. Layanan menjadi lebih cepat dan efisien serta memiliki jangkauan koneksi yang lebih luas dengan sistem online. Hidup menjadi lebih mudah dan murah. Namun demikian, digitalisasi program juga membawa dampak negatif. Peran manusia setahap demi setahap diambil alih oleh mesin otomatis. Akibatnya, jumlah pengangguran semakin meningkat. Hal ini tentu saja akan menambah beban masalah lokal maupun nasional. Oleh karena itu, 
untuk memanfaatkan peluang dan menjawab tantangan revolusi industri 4.0, dibutuhkan pendidikan karakter dan pembinaan kreativitas anak.

Pendidikan karakter dapat mengembangkan karakter yang mulia (good character) dari diri dengan mempraktikan dan mengajarkan nilainilai moral dan pengambilan keputusan yang beradab dalam berhubungan dengan Tuhan. Sedangkan seseorang yang memiliki kemampuan kreativitas akan selalu menghasilkan sesuatu gagasan, proses, metode ataupun produk baru yang orisinil, efektif yang bersifat imajinatif, dapat mengombinasikan antara beberapa temuan yang akhirnya menghasilkan suatu karya yang baru. Manusia tidak akan memiliki kepribadian yang baik jika tidak diberikan pendidikan yang sesuai dengan syarat dan nilai-nilai pendidikan karakter. Pendidikan itu juga harus melalui pembiasaan dalam kehidupan sehari-hari.

Berdasarkan hasil penelitian disimpulkan bahwa (1) nilai-nilai yang terkandung pendidikan karakter akan membentuk manusia secara utuh (holistik) yang berkarakter, yaitu mengembangkan aspek fisik, emosi, sosial, kreativitas, dan intelektual siswa secara optimal yang berlandaskan iman dan takwa kepada tuhan yang Maha Esa. (2) pendidikan karakter harus diberikan secara menyeluruh baik melalui lingkungan keluarga, sekolah, dan masyarakat. (3) dengan kreativitas yang tinggi akan membuat siswa lebih tangguh dalam menghadapi berbagai permasalahan dalam hidup. Siswa akan lebih memiliki ide, gagasan, dan penyelesaian dalam memecahkan masalah yang dihadapi. (3) era revolusi industri 4.0 bukanlah era yang harus ditakuti, namun era yang memberikan tantangan tersendiri bagi siswa yang memang harus dihadapi dengan berbagai pengetahuan dan keterampilan. (4) pendidikan karakter mempunyai peran yang sangat penting dalam membentuk kreativitas siswa sehinnga siswa lebih siap dan tangguh dalam menghadapi tantangan yang ada di era revolusi industri 4.0.

\section{DAFTAR PUSTAKA}

Aeni, A. N. (2014). Pendidikan Karakter Untuk Mahasiswa PGSD. Bandung: UPI PRESS.

Ainun, N. (2012). Character Building; Optimalisasi

Peran Pendidikan Dalam Pengembangan Ilmu dan Pembentukan Karakter Bangsa. Yogyakarta: Ar-Ruzz Media.

Alam, A. F. A., \& Rukaya. (2019). Korelasi Layana Bimbingan Karier dengan Bahasa dan Sastra di Era Revolusi Industri 4.0. Guepedia.com.

Andhara, B. A., Umaro, F. R., \& Lubis, C. H. T. (2018). Knowledge Management: Strategi Mengelola Pengetahuan Agar Unggul di Era Disrupsi. Jakarta: PT. Gramedia Pustaka Utama.

Anshari, E. S., \& Rais, A. (1988). Pak Natsir 80 Tahun; Pandangan dan Penilaian Generasi Muda. Jakarta: Abadi.

Campbell, D. (2012). Mengembangkan Kreativitas. Yogyakarta: Kanisius.

Doni Koesoema A. (2007). Pendidikan Karakter Strategi Mendidik Anak di Zaman Global. Jakarta: Grasindo.

Fadillah, M., \& Mualifatu, L. (2013). Pendidikan Karakter Anak Usia Dini. Yogyakarta: Ar ruz media.

Forkomsi FEB UGM. (2019).Revolusi Industri 4.0. Sukabumi: CV. Jejak Pusliher.

Herwibowo, Y., \& Hendroyono, T. (2004). Internet for Kids. Yogyakarta: Andi Offset.

Hidayatullah, M. F. (2010). Pendidikan Karakter Membangun Peradaban Bangsa. Surakarta: Yuna Pustaka.

Imaduddin, M. (2018). Membuat Kelas Online Berbasis Android dengan Google Classroom; Terobosan Pembelajaran Era Revolusi Industri 4.0. Yogyakarta: Garudhawacana.

J. Sumardianta dan Wahyu Kris AW. (2018). Mendidik Generasi $Z$ dan A. Jakarta: PT. Grasindo.

Kesuma, D., Triatna, C., \& Permana, J. (2011). Pendidikan Karakter Kajian Teori dan Praktik di Sekolah. Bandung: PT. Remaja RosdaKarya. Kurniawan, Y., \& Hindarsih, T. P. (2013). Character Building: Membangun Karakter Menjadi Pemimpin. Yogyakarta: Pro-U Media.

Kusnadi. (2019). Menjadi Penulis Era 4.0. Tasikmalaya: Edu Publisher.

Latuconsina, H. (2017). Kreativitas Pendobrak Belenggu, Mengantarkan Diri Menjadi Insan Kreatif dan Inovatif. Jakarta: Gramedia Pustaka Utama. 
Lickona, T. (2004). Character Matters: How to Help Our Children Develop Good Judgment, Integrity, and Other Essential Virtues. New York: Touchstone.

Maria Ellen F. Yuriaan, Prasodjo, A. (2019). Why Corporate University Mattes In Human Capital Management for Industry Revolution 4.0. Jakarta: Diandra Kreatif.

Megawangi, R. (2004). PendidikanKarakter: Solusi yang Tepat Untuk Membangun Bangsa.Jakarta: Indonesia Heritage Foundation.

Narwati, S. (2011). Pendidikan Karakter Pengintegrasian 18 Nilai PembetukKarakter dalam Mata Pelajaran. Yogyakarta: Familia.

Octavia, L., Syatibi, I., \& Ali, M. dll. (2014). Pendidikan Karakter Berbasis Tradisi Pesantren. Jakarta: Rumah Kitab.

Prastowo, A. (2015). Menyusun Rencana Pelaksanaan Pembelajaran (RPP) Tematik Terpadu Implementasi Kurikulum 2013 Untuk SD/MI. Jakarta: Kencana.

Rachmawati, Y., \& Kurniati, E. (2011). Strategi Pengembangan Kreativitas Pada Anak Usia Taman Kanak-kanak. Jakarta: Kencana.

Rosidatun. (2018). Model Implementasi Pendidikan Karakter. Kulon Gresik: Caremedia Communication.

Sagala, S. (2017). Human Capital Membangun Modal Sumber Daya Manusia Berkarakter Unggul Melalui Pendidikan Berkualitas. Depok: Kencana.

Salahudin, A., \& Alkrienciehie, I. (2017). Pendidikan Karakter Pendidikan Berbasis Agama Dan Budaya Bangsa. Bandung: Pustaka Setia. Santrock, J.W. (2007). Psikologi Perkembangan. Edisi 11 Jilid 1. Jakarta: Erlangga.

Setianto, B. D., \& Anandhita, G. (2018). Unika Dalam Wacana Publik; Transformasi Inspiratif.

Sodiq, A. (2018). Prophetic Character Building Tema Pokok Pendidikan Akhlak Menurut AlGhazali. Jakarta: Kencana.

Surya, H. (2014). Cara Luar Biasa Membuat "PEDE" (Percaya Diri) Anak. Hendra Surya

Suwito, U., Mulyadi, S., \& Hanum, F. dll. (2008). Tinjauan Berbagai Aspek Character Building; Bagaimana Mendidik Anak Berkarakter?.
Yogyakarta: Tiara Wacana.

Syarbini, A. (2014). Model Pendidikan Karakter Dalam Keluarga. Jakarta: Alex Media Komputindo.

Taylor, R. (2003). Kiat-kiat Pede Untuk Meningkatkan Rasa Percaya Diri. Jakarta: Gramedia Pustaka Utama.

Tillman, \& Diane. (2004). Pendidikan Nilai Untuk Kaum Muda Dewasa (Terjemahan Risa Pratono). Jakarta: Grasindo.

Wibowo, T. G. (2010). Menjadi Guru Kreatif. Bekasi: Media Maxima

Yaumi, M. (2014). Pendidikan Karakter: Landasan, Pilar, Dan Implementasi. Jakarta: Prenadamedia Group.

Zubaedi. (2013). Desain Pendidikan Karakter Konsepsi dan Aplikasinya dalam Lembaga Pendidikan. Jakarta: Kencana Prenada Media Group. 